\title{
“PUNITIVE DAMAGES" DO “COMMON LAW" NAS INDENIZAÇÕES POR DANO EXTRAPATRIMONIAL CAUSADO A CONSUMIDOR: UMA POSSIBILIDADE JURÍDICA NO DIREITO BRASILEIRO
}

\author{
Maria Helena Diniz ${ }^{*}$
}

\begin{abstract}
RESUMO
Procuramos analisar a importância da possibilidade jurídica de se aplicar a teoria dos punitive damages, proveniente de país de common law, no direito brasileiro, nas relações de consumo, como forma de preservar os direitos do consumidor, que vem sofrendo prejuízos extrapatrimoniais em razão de infrações cometidas pelo fornecedor, garantindo, assim, uma integral reparação do dano. A imposição de uma elevada sanção pecuniária, que vise reparar, punir e prevenir, em muito contribuiria para a diminuição da incidência de atos ilícitos contrários aos direitos da personalidade do consumidor, justificaria, apesar da omissão legal, o caráter sancionatório (reparador-compensatório-punitivo e preventivo) da responsabilidade civil nas relações de consumo, tendo como fundamento a LINDB, arts. $4^{\circ}$ e $5^{\circ}, \mathrm{CF}$ arts. $1^{\circ}$, III, $5^{\circ}, \mathrm{V}, \mathrm{XXXII}, 170$.
\end{abstract}

PALAVRAS-CHAVES: Responsabilidade civil do fornecedor; Relação de consumo; Direitos do consumidor; Dano extrapatrimonial; Punitive damages; Ativismo judicial.

\section{"PUNITIVE DAMAGES" OF COMMON LAW IN INDEMNIFICATIONS FOR EXTRA PATRIMONIAL DAMAGE TO THE CONSUMER: A LEGAL POSSIBILITY IN BRAZILIAN LAW}

\begin{abstract}
The aim of this study is to analyze the importance of the legal possibility of applying the theory of punitive damages, derived from a common law country, in Brazilian law, in consumer relations, as a way of preserving the rights of the consumer, who has suffered extra patrimonial damages, due to infringements committed by the provider, thus guaranteeing full compensation for damages. The imposition of a high pecuniary sanction, which seeks to repair, punish and prevent, would greatly contribute to reducing the incidence of unlawful acts contrary to the rights of the personality of the consumer, would justify, in spite of the legal omission, the sanctioning (compensatory- compensatorypunitive and preventive) of civil liability in consumer relations, based on LINDB, arts. 4th and 5th, CF arts. 1st, III, 5th, V, XXXII, 170.
\end{abstract}

KEYWORDS: Provider's liability; Consumer relationship; Consumer rights; Extra patrimonial damages; Punitive damages; Judicial activism.

\footnotetext{
* Doutora em Teoria Geral do Direito e Filosofia do Direito pela Pontifícia Universidade Católica de São Paulo - PUCSP. Livre-Docente e titular de Direito Civil da Pontifícia Universidade Católica de São Paulo PUCSP, por concurso de títulos e provas. Professora de Direito Civil no curso de Graduação da Pontifícia Universidade Católica de São Paulo - PUCSP. Professora de Filosofia do Direito, de Teoria Geral do Direito e de Direito Civil Comparado nos cursos de Pós-Graduação (Mestrado e Doutorado) em Direito da Pontifícia Universidade Católica de São Paulo - PUCSP. Coordenadora do Núcleo de Pesquisa em Direito Civil Comparado nos Cursos de Pós-Graduação em Direito da Pontifícia Universidade Católica de São Paulo PUCSP. Presidente do Instituto Internacional de Direito (IID). E-mail: mari.santiago@ terra.com.br.
} 


\section{INTRODUÇÃO: RELAÇÃO CONSUMERISTA: NOÇÕES GERAIS, DIREITOS DO CONSUMIDOR E DEVERES DO FORNECEDOR}

A relação de consumo é a existente entre consumidor e fornecedor. O consumidor é não só a pessoa física ou jurídica que vem a utilizar produto ou serviço como destinatário final, mas também a coletividade de pessoas, mesmo indeterminável, que intervém nas relações de consumo (Lei n. 8.0878/90, art. $2^{\circ}$, parágrafo único).

O consumidor ou usuário de produtos fabricados ou elaborados - isto é, resultantes da transformação de outras coisas pela atividade do homem a elas aplicada (exclui, portanto, os que são consumidos in natura, como legumes, frutas e verduras) - pode sofrer danos em sua saúde ou em seus bens em razão de defeito ou falha de fabricação. Realmente, pode ocorrer que alguém adquira automóvel numa a agência e venha a sofrer um grave acidente em virtude de falha no material empregado no sistema de freamento ou de defeito na direção ou de outra imperfeição de fabricação, ou que uma compre num mercado um produto comestível em mau estado ou com substâncias tóxicas e contraia uma intoxicação por tê-lo ingerido.

São frequentes tais acidentes ante a crescente utilização de produtos elaborados, sejam móveis ou imóveis, materiais ou imateriais (art. $3^{\circ}, \S 1^{\circ}$, da Lei n. 8.078/90), que são produzidos em massa, devido ao progresso tecnológico, pois, apesar do emprego de medidas de controle e segurança, grande é a porcentagem de mercadorias que entram no processo de comercialização sem condições de serem consumidas ou usadas, por serem defeituosas. Urge, portanto, procurar soluções técnicas que melhorem os sistemas de controle de produção e de conservação e aumentar a proteção legal, de modo que o lesado possa obter a indenização a que faz jus.

O mesmo se diga em relação ao usuário de serviços prestados, ou seja, de qualquer atividade fornecida no mercado de consumo, mediante remuneração, inclusive as de natureza bancária, financeira, de crédito e securitária, salvo as decorrentes das relações de caráter trabalhista $\left(\operatorname{art} .3^{\circ}, \S 2^{\circ}\right)$.

Para dar ao consumidor maior proteção e garantia à saúde e à reparação dos danos causados por produtos elaborados defeituosos, a responsabilidade do fabricante deve ser objetiva. Todavia, nem sempre o fabricante será responsável, pois seu dever ressarcitório subordinar-se-á à verificação de que o prejuízo causado à vítima adveio de um defeito do 


\section{“PUNITIVE DAMAGES” DO “COMMON LAW" NAS INDENIZAÇÕES POR DANO \\ EXTRAPATRIMONIAL CAUSADO A CONSUMIDOR: UMA POSSIBILIDADE JURÍDICA NO \\ DIREITO BRASILEIRO}

produto.

Ante a gravidade desse problema e a vulnerabilidade do consumidor no mercado de consumo, seria conveniente que houvesse normas que impusessem ao fabricante ou produtor uma responsabilidade objetiva, que levasse a uma socialização dos riscos. A responsabilidade do produtor poderia transferir-se para o custo de produção, de modo que ele pudesse contratar um seguro de responsabilidade civil que cobrisse os riscos e garantisse aos lesados o ressarcimento a que têm direito. Por isso, a Constituição Federal de 1988, em defesa do consumidor, no art. 200, I e VI, já que pelo art. 5, XXXII, compete ao Estado promovê-la, estabelece atribuições ao Sistema Único de Saúde, cabendo à lei ordinária baixar normas, não só controlar e fiscalizar procedimentos, produtos e substâncias de interesse para a saúde e participar da produção de medicamentos, mas também fiscalizar e inspecionar alimentos, compreendido o controle de seu teor nutricional, bem como bebidas e águas para consumo humano.

Além disso, o art. 170, V, dispõe: “A ordem econômica, fundada na valorização do trabalho humano e na livre iniciativa, tem por fim assegurar a todos existência digna, conforme os ditames da justiça social, observando o princípio da defesa do consumidor". Como a saúde é dever do Estado (art. 196), a Constituição de 1988, no art. 220, § 4º, defendendo o consumidor, prescreve que a propaganda comercial de tabaco, bebidas alcoólicas, agrotóxicos, medicamentos e terapias estará sujeita a restrições legais e deverá conter, sempre que necessário, advertência sobre os malefícios de seu uso.

A Lei n. 8.078/90, que dispõe sobre a proteção do consumidor, veio a estabelecer normas de ordem pública e interesse social, nos termos dos arts. $5^{\circ}$, XXXII, e 170, V, da Constituição Federal, e art. 48, de suas Disposições Transitórias (art. $1^{\circ}$ ) (DINIZ, 2017, pp. 500-506; FILOMENO, 2004, pp. 98-128; BITTAR, 2002, pp. 135-156; ZANELATTO, 2:34-57).

O fabricante, vendedor ou prestador de serviço terá o dever de informar o consumidor de todos os caracteres dos produtos e serviços oferecidos no mercado, indicando suas condições de uso, podendo para isso efetuar, sem abusos, contrato de merchandising, com o escopo de comercializar obras ou criações intelectuais aplicadas a produtos elaborados, mediante retribuição convencionada. Toda informação ou publicidade, suficientemente precisa, veiculada por qualquer forma ou meio de comunicação com relação a 
produtos e serviços oferecidos ou apresentados, obrigará o fornecedor que a fizer veicular ou dela se utilizar e integrará o contrato que vier a ser celebrado (art. 30). A oferta e apresentação de produtos ou serviços deverá não só conter informações corretas, claras, precisas, ostensivas e em língua portuguesa sobre suas características, qualidades, quantidade, composição, preço (Dec. n. 5.903/2006), garantia, prazos de validade e origem, entre outros dados, bem como sobre os riscos que apresentam à saúde e segurança dos consumidores, mas também evitar técnica comercial abusiva, por exemplo venda casada de livros de livros (CDC, art. $6^{\circ}, \mathrm{IV}, 39$, I e IV; BAASP, 3027:2), sob pena de rescisão contratual, devolução do objeto e restituição integral dos valores.

O consumidor terá, pela Lei n. 8.078/90, a proteção dos seguintes direitos:

a) à proteção da vida, saúde e segurança contra os riscos provocados por práticas no fornecimento de produtos e serviços considerados perigosos ou nocivos (arts. $6^{\circ}, 1 ; 8^{\circ}$ a 10); b) à educação e divulgação sobre o consumo adequado dos produtos e serviços, asseguradas a liberdade de escolha e a igualdade nas condições (art. $6^{\circ}$, II); c) à informação adequada e clara sobre os diferentes produtos e serviços, com especificação correta de quantidade, características, composição, qualidade, tributos incidentes e preço, bem como sobre os riscos que apresentem (art. $6^{\circ}$, III, com a alteração da Lei n. 12.741/2012); d) à proteção contra a publicidade enganosa e abusiva, métodos comerciais coercitivos ou desleais, bem como contra práticas e cláusulas abusivas ou impostas no fornecimento de produtos e serviços (art. $6^{\circ}$, inciso IV); e) à modificação das cláusulas contratuais que estabeleçam prestações desproporcionais ou sua revisão em razão de fatos supervenientes que as tornem excessivamente onerosas (art. $\left.6^{\circ}, \mathrm{V}\right)$; f) à efetiva prevenção e reparação de danos patrimoniais e morais, individuais, coletivos e difusos (art. $\left.6^{\circ}, \mathrm{VI}\right)$; g) ao acesso aos órgãos judiciários e administrativos, com vistas à prevenção ou reparação de danos patrimoniais e morais, individuais coletivos ou difusos, assegurada a proteção jurídica, administrativa e técnica aos necessitados (art. $\left.6^{\circ}, \mathrm{VII}\right)$; h) à facilitação da defesa de seus direitos, inclusive com a inversão do ônus da prova, a seu favor, no processo civil, quando, a critério do juiz, for verossímil a alegação ou quando for ele hipossuficiente, segundo as regras ordinárias de experiências (art. 6, VIII; BAASP, 2.671:1.813-04); i) à prestação dos serviços públicos em geral $\left(\operatorname{art.} 6^{\circ}, \mathrm{X}\right)$, adequada e eficaz; j) à reclamação pelos vícios aparentes dentro do prazo decadencial de trinta dias, se se tratar de fornecimento de serviço e de produtos não duráveis, ou noventa dias, se duráveis, contado da data da entrega efetiva do produto ou do término da 


\section{“PUNITIVE DAMAGES” DO “COMMON LAW" NAS INDENIZAÇÕES POR DANO EXTRAPATRIMONIAL CAUSADO A CONSUMIDOR: UMA POSSIBILIDADE JURÍDICA NO \\ DIREITO BRASILEIRO}

execução dos serviços. E, se o vício for oculto, tal prazo computar-se-á no instante em que o defeito ficar evidenciado; k) à pretensão à reparação pelos danos causados por fato do produto ou do serviço, dentro do prazo prescricional de cinco anos, contado a partir do conhecimento do dano ou de sua autoria (art. 27); 1) à não exposição a ridículo ou a constrangimento ou ameaça na cobrança de seus débitos (arts. 42 e 42-A, acrescentado pela Lei n. 12.039/2009); m) à repetição do indébito, por valor igual ao dobro do que pagou em excesso, acrescido de correção monetária e juros legais, salvo hipótese de engano justificável, desde que tenha sido cobrado em quantia indevida (art. 42, parágrafo único); n) ao acesso às informações existentes em cadastros, fichas, registros e dados pessoais e de consumo arquivados sobre ele, bem como sobre respectivas fontes. O consumidor, sempre que encontrar inexatidão nos seus dados e cadastros, poderá exigir sua imediata correção, devendo o arquivista, no prazo de cinco dias úteis, comunicar a alteração aos eventuais destinatários das informações incorretas. Consumada a prescrição relativa à cobrança de débitos do consumidor, não serão fornecidas, pelos respectivos Sistemas de Proteção ao Crédito, quaisquer informações que possam impedir ou dificultar novo acesso ao crédito junto aos fornecedores (art. $43, \S \S 1^{\circ}$ ao $5^{\circ}$ ).

Tais direitos não excluirão outros decorrentes de tratados ou convenções internacionais de que o Brasil seja signatário, da legislação interna ordinária, de regulamentos expedidos pelas autoridades administrativas competentes, bem como dos que derivem dos princípios gerais do direito, analogia, costumes e equidade (art. $7^{\circ}$ ).

Inúmeros são os deveres do fornecedor; dentre outros, apontamos os de:

A) Atender às proibições, contidas no art. 39, I a IX, de:

a) condicionar o fornecimento de produto ou de serviço ao fornecimento de outro produto ou serviço, bem como, sem justa causa, a limites quantitativos; b) recusar atendimento às demandas dos consumidores, na exata medida de suas disponibilidades de estoque e, ainda, de conformidade com os usos e costumes; c) enviar ou entregar ao consumidor, sem solicitação prévia, qualquer produto, ou fornecer qualquer serviço, mesmo se se tratar de amostras grátis, sem obrigação de pagamento (art. 39, parágrafo único); d) prevalecer-se da fraqueza ou ignorância do consumidor, tendo em vista sua idade, saúde, escolaridade ou condição social, para impingir-lhe produtos ou serviços; e) exigir do consumidor vantagem manifestamente excessiva; f) executar serviços sem a prévia elaboração de orçamento e autorização expressa do 
consumidor, ressalvadas as decorrentes de práticas anteriores entre as partes; g) repassar informação depreciativa, referente a ato praticado pelo consumidor no exercício de seus direitos; h) colocar, no mercado de consumo, qualquer produto ou serviço em desacordo com as normas expedidas pelos órgãos oficiais competentes ou, se normas específicas não existirem, pela Associação Brasileira de Normas ou outra entidade credenciada pelo Conselho Nacional de Metrologia, Normalização e Qualidade Industrial - Conmetro; i) deixar de estipular prazo para o cumprimento de sua obrigação ou a fixação de seu termo inicial a seu exclusivo critério.

B) Entregar ao consumidor orçamento prévio discriminando o valor da mão de obra, dos materiais e equipamentos a serem empregados, as condições de pagamento, bem como as datas de início e término dos serviços. Uma vez aprovado consumidor, o orçamento obrigará os contraentes e somente pode ser alterado mediante livre negociação das partes. O consumidor não responderá por quaisquer ônus ou acréscimos decorrentes da contratação de serviços de terceiros, não previstos no orçamento prévio (art. $40, \S \S 1^{\circ}$ a $3^{\circ}$ ).

C) Respeitar os limites oficiais, no caso de fornecimento de produtos e serviços sujeitos ao regime de controle ou de tabelamento de preços, sob pena de, não o fazendo, responder pela restituição da quantia recebida em excesso, monetariamente atualizada, podendo o consumidor exigir, a sua escolha, o desfazimento do negócio, sem prejuízo de outras sanções cabíveis (art. 41).

D)Responsabilizar-se pelos danos patrimoniais e morais causados ao consumidor, ressarcindo-o. E, se a ofensa tiver mais de um autor, todos responderão solidariamente pela reparação dos prejuízos (art. $7^{\circ}$, parágrafo único).

E) Comercializar: a) revistas e publicações atendendo à Lei n. 8.069/90 (arts. 78, parágrafo único, e 79), respeitando os valores éticos e sociais da pessoa e da família, sob pena de pagar multa de três a vinte salários de referência, duplicando-se tal pena se reincidir, sem prejuízo de apreensão da revista ou publicação (Lei n. 8.069/90, art. 257); b) fitas de programação de vídeo informando sobre a natureza da obra e faixa etária a que se destinam (Lei n. 8.069/90, art. 77), sob multa de três a vinte salários de referência e de fechamento do estabelecimento por quinze dias, por ordem judicial, em caso de reincidência (Lei n. 8.069/90, art. 256); c) armas, munições e explosivos; bebidas alcoólicas; produtos causadores de dependência física ou psíquica; 


\section{“PUNITIVE DAMAGES” DO “COMMON LAW" NAS INDENIZAÇÕES POR DANO EXTRAPATRIMONIAL CAUSADO A CONSUMIDOR: UMA POSSIBILIDADE JURÍDICA NO \\ DIREITO BRASILEIRO}

fogos de artifício que possam causar dano físico se utilizados indevidamente; bilhetes lotéricos e equivalentes, apenas a maiores (Lei n. 8.069/90, art. 81), sob pena de detenção de seis meses a dois anos e multa (Lei n. 8.069/90, arts. 242 a 244).

F) Afixar, se responsável por diversão e espetáculo público, em local visível, informação sobre a natureza do espetáculo e faixa etária, apenas permitindo entrada de menores em espetáculos que lhes forem recomendado em razão de sua idade e, se se tratar de criança até 10 anos, apenas se acompanhada de seus pais ou responsável (Lei n. 8.069/90, arts. 74 e 75), sob pena de pagar de três a vinte e três salários de referência, duplicada no caso de reincidência, e, no caso de permissão de ingresso de menor a espetáculo impróprio, poderá, se reincidir, sofrer o fechamento do estabelecimento por quinze dias, em razão, de ordem judicial (Lei n. 8.069/90, arts. 252, 253, 255 e 258).

G) Exibir, sendo emissora de rádio e televisão, em horário recomendado a menores, programas educacionais, culturais, artísticos e informativos, apresentando, antes de sua transmissão, aviso de sua classificação (Lei n. 8.069/90, art. 76 e parágrafo único), sob pena de multa de vinte a cem salários de referência, aplicada em dobro se houver reincidência, podendo ainda, o juiz determinar a suspensão da programação da emissora por até dois dias (lei n. 8.069/90, art. 254).

H) Permitir apenas maiores no recinto de seu estabelecimento se explorar comercialmente bilhar, sinuca ou congênere, jogos ou apostas (Lei n. 8.069/90, art. 80).

I) Não transportar criança para fora da comarca onde reside, desacompanhada dos pais ou responsável, sem expressa autorização judicial (Lei n. 8.069/90, art. 83), pois se o fizer poderá ser punido com multa de três a vinte salários de referência, duplicada se reincidir (Lei n. $8.069 / 90$, art. 251).

J) Não hospedar menor, desacompanhado dos pais ou responsável, ou sem autorização judicial, em hotel, pensão, motel etc. Se permitir tal hospedagem, será punido com multa de dez a cinquenta salários de referência, e na hipótese de reincidência o juiz poderá determinar o fechamento do estabelecimento por até quinze dias (Lei n. 8.069/90, art. 250).

K) Não contracenar, produzir, nem dirigir representação teatral, televisa ou cinematográfica, nem fotografar ou publicar fotografia envolvendo menor em cena de sexo explícito ou pornográfica, sob pena de reclusão quatro anos (Lei n. 8.069/90, arts. 240 e 241). 
L) Avisar em rótulos de embalagens de alimentos industrializados que contêm glúten, para prevenir o consumidor da síndrome celíaca (Lei n. 8.543/92).

M) Manter amostras sem lacre dos produtos à venda, para exame do consumidor (Lei n. 8.124/92 do Estado de São Paulo) etc. (DINIZ, 2016, pp. 520-529).

\section{RESPONSABILIDADE CIVIL NAS RELAÇÕES DE CONSUMO}

A responsabilidade civil por dano a consumidor é um dos temais mais problemáticos da atualidade jurídica, pela sua grande expansão e reflexos nos direitos da personalidade, gerando perigo à integridade da pessoa e do seu patrimônio, tornando imprescindível a criação de soluções que sanem integralmente tais lesões (LOPES,1962, pp. 186-187; LARENZ, 1959; MIRANDA, 2016, p. 19).

Toda manifestação de atividade que causa prejuízo traz em si o problema da responsabilidade, que não é fenômeno exclusivo da vida jurídica, mas de todos os domínios da vida social (MARTON, 1938, p. 304).

Por repercutir em todas as atividades humanas, tutelando inclusive os direitos da personalidade, múltiplos são os dissídios doutrinários e díspares são os posicionamentos dos tribunais, "quanto à definição de seu alcance, à enunciação de seus pressupostos e à sua própria textura", tornando-se um dos árduos e complexos problemas jurídicos e de mais difícil sistematização (MENDONÇA, 1938, p. 428; LOPES, 1962, p. 186; STOCCO, 2003, pp. 780837; BITTAR, 2002, p. 4).

Grande é a importância da responsabilidade civil, nos tempos atuais, por se dirigir à restauração de um equilíbrio moral e patrimonial desfeito e à redistribuição da riqueza de conformidade com os ditames da justiça, tutelando a pertinência de um bem, com todas as suas utilidades, presentes e futuras, a um sujeito determinado, pois, como pondera José Antônio Nogueira, a questão da responsabilidade é o próprio problema do direito, visto que "todo o direito assenta na ideia da ação, seguida da reação, de restabelecimento de uma harmonia quebrada". O interesse em restabelecer o equilíbrio violado pelo dano é a fonte geradora da responsabilidade civil. A obrigação de indenizar, fundada sobre a responsabilidade civil, visa suprimir a diferença entre a situação do credor, tal como esta se apresenta em consequência do prejuízo, e a que existiria sem este último fato. A indenização é estabelecida em atenção ao dano e à situação do lesado, que deverá ser restituído à situação 


\section{“PUNITIVE DAMAGES” DO “COMMON LAW" NAS INDENIZAÇÕES POR DANO \\ EXTRAPATRIMONIAL CAUSADO A CONSUMIDOR: UMA POSSIBILIDADE JURÍDICA NO \\ DIREITO BRASILEIRO}

em que estaria se não tivesse ocorrido a ação do lesante.

A responsabilidade civil cinge-se, portanto, à reparação do dano causado a outrem, desfazendo tanto quanto possível seus efeitos, restituindo o prejudicado ao status quo ante. A responsabilidade civil constitui uma relação obrigacional que tem por objeto a prestação de ressarcimento. Tal obrigação de ressarcir o prejuízo causado pode originar-se: a) da inexecução de contrato; e b) da lesão a direito subjetivo, sem que preexista entre lesado e lesante qualquer relação jurídica que a possibilite (LIMA, 83:385; PLANIOL, RIPERT E ESMEIN. 1952; DIAS, 1979, p. 22; GOMES, 1976, p. 339).

Visa, portanto, garantir o direito do lesado à segurança, mediante o pleno ressarcimento dos danos que sofreu, restabelecendo-se na medida do possível o status quo ante. Logo, o princípio que domina a responsabilidade civil na era contemporânea é o da restitutio in integrum, ou seja, da reposição completa da vítima à situação anterior à lesão, por meio de uma reconstituição natural, de recurso a uma situação material correspondente ou de indenização que represente do modo mais exato possível o valor do prejuízo no momento de seu ressarcimento, respeitando assim, sua dignidade.

A responsabilidade civil constitui uma sanção civil, por decorrer de infração normativa de direito privado, cujo objetivo é o interesse particular, e, em sua natureza, é compensatória, por abranger indenização ou reparação de dano causado por ato ilícito, contratual ou extracontratual e por ato lícito. A responsabilidade, observa Marton, é a situação de quem, tendo violado uma norma, vê-se exposto às consequências desagradáveis, decorrentes dessa violação, traduzidas em medidas que a autoridade encarregada de velar pela observância do preceito lhe imponha. Vem a ser uma reação provocada pela infração a um dever preexistente. É, desse modo, a consequência que o agente, em virtude de violação de dever, sofre pela prática de seus atos. Tem uma função essencialmente indenizatória, ressarcitória ou reparadora (AMARAL NETO, v. 65, p. 346; DINIZ, 1999, pp. 101-102). Portanto, dupla é a função da responsabilidade: a) garantir o direito do lesado à segurança; b) servir como sanção civil, de natureza compensatória, mediante a reparação do dano causado à vítima, punindo o lesante e desestimulando a prática de atos lesivos (Telles Jr., 1980, cap. VII).

Essa função reparadora e compensatória, como veremos, será insuficiente para ressarcir integralmente o dano extrapatrimonial sofrido pelo consumidor. 
Por isso urge lembrar a lição de Marcelo Benacchio (Benacchio, 98: 38-39), que observa que Beck repensa a responsabilidade civil e vislumbra que deve ter função não só punitiva, reparatória, mas também preventiva, atuando, nesta hipótese, antes da ocorrência do dano, evitando novos danos e impedindo a realização do dano por meio de ações concretas destinadas a evitá-los. Seria útil na tutela de direitos da personalidade, direito ambiental e direitos difusos. A responsabilidade civil preventiva reger-se-ia pelos princípios da prevenção, que envolve riscos determinados e da precaução, que trata dos riscos incertos, prováveis. É uma garantia à simples ameaça de dano $\left(\mathrm{CF}\right.$, arts. $5^{\circ}, \mathrm{V}, \mathrm{X}, \mathrm{XXXV}, 225, \S 1^{\circ}$, V e VII; CC; art. 12, $\mathrm{CDC}$, art. $6^{\circ}$, I e VI). O dano punitive (indenização punitiva), não previsto legalmente no Brasil, decorre do direito anglo-saxão e consiste numa quantia pecuniária paga à vítima de um ilícito, sanando seu prejuízo extrapatrimonial integralmente, indo o restante para um fundo público, para beneficiar outras pessoas, tal como ocorre nas hipóteses de multas previstas na Lei n. 8.078/90, art. 56, transferindo-se ao patrimônio do lesado apenas o necessário à reparação completa do dano sofrido por ele, a título de punição do ofensor, que atuou com culpa grave, com o escopo de desestimulá-lo a praticar novamente o mesmo ato ou conduta socialmente inaceitável, e de servir de exemplo aos demais membros da coletividade. Atenderia, portanto, a finalidade de punição, prevenção e exemplaridade (BENACCHIO, 98: 38-39; CUNHA, 2012; VARESANO, 30: 9-33).

Há responsabilidade do fornecedor:

A) pelo fato do produto e do serviço, nos casos arrolados pela Lei n. 8.078/90: a) o fabricante, o produtor, o construtor, nacional ou estrangeiro, e o importador responderão, independentemente da existência de culpa, pela reparação dos danos causados aos consumidores por defeitos decorrentes de projeto, fabricação, construção, montagem, fórmulas, manipulação, apresentação ou acondicionamento de seus produtos, bem como por informações insuficientes ou inadequadas sobre sua utilização e riscos. O produto será tido como defeituoso quando não oferecer a segurança que dele legitimamente se espera, levando-se em consideração as circunstâncias relevantes, entre as quais: sua apresentação, o uso e os riscos que razoavelmente dele se esperam e a época em que foi colocado em circulação. O fabricante, o construtor, o produtor ou importador só não serão responsabilizados quando provarem: que não colocaram o produto no mercado; que, embora hajam colocado o produto no mercado, o defeito inexiste; que houve culpa exclusiva do consumidor ou de terceiro (art. 12 e $\$ \S 1^{\circ}$ a $3^{\circ}$ ). Portanto, a responsabilidade do fabricante 


\section{“PUNITIVE DAMAGES” DO “COMMON LAW" NAS INDENIZAÇÕES POR DANO \\ EXTRAPATRIMONIAL CAUSADO A CONSUMIDOR: UMA POSSIBILIDADE JURÍDICA NO \\ DIREITO BRASILEIRO}

é objetiva, independentemente de averiguação de culpa.

O art. 931 do Código Civil amplia o conceito de fato do produto existente no art. 12 do CDC ao imputar responsabilidade civil à empresa e empresários individuais vinculados à circulação dos produtos e ao incluir os riscos do desenvolvimento (Enunciados n. 42 e 43 do Centro de Estudos Judiciários do Conselho da Justiça Federal); b) o empresário ou comerciante será responsável quando: o fabricante, o construtor, o produtor ou o importador não puderem ser identificados; o produto for fornecido sem identificação clara do seu fabricante, produtor, construtor ou importador; não conservar adequadamente os produtos perecíveis. E aquele que efetivar o pagamento ao prejudicado poderá exercer o direito de regresso contra os demais responsáveis, segundo sua participação na causação do evento danoso (art. 13, I a III e parágrafo único); c) o fornecedor de serviços responderá, independentemente da existência de culpa, pela reparação dos danos causados aos consumidores por defeitos relativos à prestação dos serviços, bem como por informações insuficientes ou inadequadas sobre sua fruição e riscos. O serviço será defeituoso quando não fornecer a segurança que o consumidor dele pode esperar, levando-se em consideração as circunstâncias relevantes, entre as quais: o modo de seu fornecimento; o resultado e os riscos que razoavelmente dele se esperam; a época em que foi fornecido. $O$ fornecedor de serviços só não será responsabilizado se provar tendo prestado o serviço, o defeito inexiste e que houve culpa exclusiva consumidor ou de terceiro.

A responsabilidade pessoal dos profissionais liberais será apurada diante a verificação de culpa ( $\operatorname{art.} 14, \S \S 1^{\circ}$ a $4^{\circ}$ ), sendo, portanto, subjetiva se a obrigação for de meio; mas sendo obrigação de resultado, deve ser objetiva sua responsabilidade, na lição de Nelson Nery Jr. e Oscar Ivan Prux.

Consagra, assim, o Código de Defesa do Consumidor a responsabilidade objetiva, ressarcindo os danos físico-psíquicos causados ao consumidor e demais vítimas do evento (Lei n. 8.078/90, art. 17) por vício de qualidade por insegurança.

B) por vício do produto e do serviço

Haverá responsabilidade solidária dos fornecedores de produtos de consumo duráveis ou não duráveis pelos vícios de qualidade ou quantidade que os tornem impróprios ou inadequados ao consumo a que se destinam ou thes diminuam o valor, assim como por aqueles decorrentes da disparidade, com as indicações constantes do recipiente, da embalagem, 
rotulagem ou mensagem publicitária, respeitadas as variações decorrentes de sua natureza, podendo o consumidor exigir a substituição das partes viciadas (Lei n. 8.078/90, art. 18).

Se o vício não for sanado no prazo máximo de trinta dias, poderá o consumidor exigir, alternativamente e à sua escolha: a substituição do produto por outro da mesma espécie, em perfeitas condições de uso; a restituição imediata da quantia paga (BAASP, 2.658:1.774; 2.758:6213), monetariamente atualizada, sem prejuízo de eventuais perdas e danos; ou abatimento proporcional do preço (art. 18, § 1; BAASP, 2.757:2082-06) .

Poderão as partes convencionar a redução ou ampliação desse prazo, não podendo, contudo, ser inferior a sete nem superior a cento e oitenta dias. Nos contratos por adesão, a cláusula de prazo deverá ser convencionada em separado, por meio de manifestação expressa do consumidor (art. $18, \S 2^{\circ}$ ).

O consumidor poderá fazer uso imediato daquelas alternativas sempre que, em razão da extensão do vício, a substituição das partes viciadas puder comprometer a qualidade ou características do produto, diminuir-lhe o valor ou se tratar de produto essencial (art. 18, $\S 3^{\circ}$ ). Tendo o consumidor optado pela troca do bem e não sendo possível a sua substituição, poderá haver substituição por outro de espécie, marca ou modelo diversos, mediante complementação ou restituição de eventual diferença de preços (art. 18, § $4^{\circ}$ ).

No caso de fornecimento de produtos in natura, será responsável perante o consumidor o fornecedor imediato, exceto quando identificado claramente seu produtor $\left(\right.$ art. $\left.18, \S 5^{\circ}\right)$.

São impróprios ao uso e consumo: os produtos cujos prazos de validade estejam vencidos; os produtos deteriorados, alterados, adulterados, avariados, falsificados, corrompidos, fraudados, nocivos à vida ou à saúde, perigosos ou, ainda, aqueles em desacordo com as normas regulamentares de fabricação, distribuição ou apresentação; os produtos que, por qualquer motivo, revelem-se inadequados ao fim a que se destinam $\left(\right.$ art. $\left.18, \S 6^{\circ}\right)$.

Os fornecedores responderão solidariamente pelos vícios de quantidade do produto sempre que, respeitadas as variações decorrentes de sua natureza, seu conteúdo líquido for inferior às indicações constantes do recipiente, da embalagem, rotulagem ou de mensagem publicitária, podendo o consumidor exigir, alternativamente e à sua escolha: o abatimento proporcional do preço; a complementação do peso ou medida; a substituição do produto por outro da mesma espécie, marca ou modelo, sem os aludidos vícios; ou a restituição 


\section{“PUNITIVE DAMAGES” DO “COMMON LAW" NAS INDENIZAÇÕES POR DANO EXTRAPATRIMONIAL CAUSADO A CONSUMIDOR: UMA POSSIBILIDADE JURÍDICA NO \\ DIREITO BRASILEIRO}

imediata da quantia paga, monetariamente atualizada, sem prejuízo de eventuais perdas e danos (art. 19, I a IV).

Se houver opção pela substituição do produto e esta for impossível, na troca entregar-se-á outro diverso, complementando-se ou restituindo-se a diferença de preço se houver (art. 19, $\left.\S 1^{\circ}\right)$.

O fornecedor imediato será responsável quando fizer a pesagem ou a medição e o instrumento utilizado não estiver aferido segundo os padrões oficiais (art. 19, $\S 2^{\circ}$ ).

O fornecedor de serviços responderá pelos vícios de qualidade que os tornarem impróprios ao consumo ou lhes diminuírem o valor, assim como por aqueles decorrentes da disparidade com as indicações constantes da oferta ou mensagem publicitária, podendo o consumidor exigir, alternativamente e à sua escolha: a reexecução dos serviços, sem custo e quando cabível; a restituição imediata da quantia paga, monetariamente atualizada, sem prejuízo de eventuais perdas e danos; ou o abatimento proporcional do preço (art. 20, I a III).

A reexecução dos serviços poderá ser confiada a terceiros devidamente capacitados, por conta e risco do fornecedor ( $\operatorname{art.} 20, \S 1^{\circ}$ ).

Serão impróprios os serviços que se mostrarem inadequados para os fins que razoavelmente deles se esperam, bem como aqueles que não atenderem às normas regulamentares de prestabilidade (art. $20, \S 2^{\circ}$ ).

No fornecimento de serviços que tiverem por finalidade a reparação de qualquer produto, considerar-se-á implícita a obrigação do fornecedor de empregar componentes de reposição originais adequados e novos, ou que mantiverem as especificações técnicas do fabricante, salvo, quanto a estes últimos, autorização em contrário do consumidor (art. 21).

Os órgãos públicos, por si ou suas empresas, concessionárias, permissionárias ou sob qualquer outra forma de empreendimento, serão obrigadas a fornecer serviços adequados, eficientes, seguros e, quanto aos essenciais, contínuos. E na hipótese de descumprimento, total ou parcial, dessas obrigações, serão as pessoas jurídicas compelidas a cumpri-las e a reparar os danos causados (art. 22, parágrafo único).

A ignorância do fornecedor sobre os vícios de qualidade por inadequação dos produtos e serviços não o eximirá de responsabilidade (art. 23).

A garantia legal de adequação do produto ou serviço independerá de termo expresso, vedada a exoneração contratual do fornecedor (art. 24). 
Será proibida a estipulação contratual de cláusula que impossibilite, exonere ou atenue a obrigação de indenizar (art. 25).

Caso haja mais de um responsável pelo dano, todos responderão solidariamente pela reparação $\left(\operatorname{art} .25, \S 1^{\circ}\right.$ ). E se o dano for causado por componente ou peça incorporada ao produto ou serviço, serão responsáveis solidários seu fabricante, construtor ou importador e o que realizou a incorporação (art. $25, \S 2^{\circ}$ ).

Em suma, ter-se-á responsabilidade subjetiva juris et de jure do fornecedor se o produto ou serviço vier a lesar patrimonialmente o consumidor, em razão de vício de quantidade ou de qualidade por inadequação (DINIZ, 2016, pp. 529-534).

\section{QUESTÕES DOS PUNITIVE DAMAGES NOS CASOS DE DANO EXTRAPATRIMONIAL CAUSADO A CONSUMIDOR}

Nos EUA, os autores definem os punitive damages, observa Wladimir A. M. Falcão Cunha, como uma retribuição monetária, desconectada do montante principal compensatório, que se impõe como (1) punição ao ofensor por sua conduta dolosa ou culposa particularmente negativa ou ultrajante, seja em virtude de (a) intenção deliberada, opressão, malícia, fraude, arbitrariedade, ultraje, ou de (b) severa falta de cuidado ou indiferença com os direitos alheios, apesar da consciência dos riscos (recklessness), ou ainda de, (c) em parte dos Estados americanos, culpa grave (gross negligence), bem também como (2) prevenção e dissuasão para que não venha a repeti-la, assim como para que os demais membros da comunidade não venham a praticá-la (CUNHA, 2012, pp. 94, 100, 116, 167, 169-170; VIEGAS, I101: 69103). A indenização punitiva por dano moral, advinda dos USA, pode coibir abusos praticados contra o consumidor e solucionar de forma favorável litígios nas relações de consumo.

Os danos morais constituem uma violação ao princípio do respeito à dignidade humana $\left(\mathrm{CF} / 88\right.$, art. $1^{\circ}$, III) e aos direitos da personalidade e justificam a aplicação dos punitive damages, que, nos USA não é automática, pois somente serão infligidos ao ofensor em situação altamente qualificada de forma negativa, ultrajante, dolosa, repreensível, injusta e repugnante (OWEN, Vol. 74, p. 1.287).

O dano punitivo é uma pena privada, adicional às indenizações compensatórias por dano extrapatrimonial que, eventualmente, o lesado possa ter experimentado (SANDOVAL e PIZARRO, 2010, pp. 65-96; CC argentino, art. 52), inclusive em certos casos de 


\title{
“PUNITIVE DAMAGES” DO “COMMON LAW" NAS INDENIZAÇÕES POR DANO EXTRAPATRIMONIAL CAUSADO A CONSUMIDOR: UMA POSSIBILIDADE JURÍDICA NO \\ DIREITO BRASILEIRO
}

responsabilidade objetiva no direito do consumidor (p. ex. sempre que houver no mercado produto perigoso ou que contenha defeito que possa provocar grave dano por reger relação jurídica marcada pelo desequilíbrio entre fornecedor e consumidor, ou seja, pela hipossuficiência e pela vulnerabilidade). Deveras, inegável é a ocorrência de danos contratuais ao consumidor provocados por subterfúgios, supostas vantagens ao consumidor, cláusulas abusivas travestidas de licitude e de não abusividade (CUNHA, 2012, p. 149). Há também, nas relações de consumo, danos não contratuais ou pré-contratuais, como por ex. na equiparação consumidor-bystander, nos movimentos de oferta e publicidade, nas práticas abusivas, tendentes à contratação, poderiam ser enquadradas como ilícitos extracontratuais.

Daí dizer Wladimir A. Marinho Falcão Cunha (CUNHA, 2012, pp. 177-178):

\begin{abstract}
Assim, por exemplo, se nas relações de consumo, se observa que a imposição da cláusula abusiva liga-se não só à defesa legítima de posição contratual do fornecedor, mas extremamente à malícia empresarial na relação jurídicoeconômica para com o consumidor, como indução ao erro, tentativa de fraude etc, está-se diante da possibilidade de imposição de danos punitivos contratuais. De igual modo, a realização de prática abusiva no mercado de consumo, nos moldes tipificados no art. 39 do Código de Defesa do Consumidor, ou em moldes similares, desde que aliada à prática do dolo, da malícia ou da culpa qualificada, pode também trazer abertura para casos abusivos e, portanto, para a imposição de danos punitivos. Um caso paradigmático, nesse sentido, pode ser imaginado no aproveitamento deliberado da situação de inexperiência contratual de idosos aposentados para fins de estabelecimento de contratatação de crédito, geralmente mediante desconto consignado diretamente na folha de pagamento, ou outra espécime de contrato qualquer. Nesses casos, o atrelamento da malícia empresarial caracterizada por publicidade enganosa, cobrança de hidden fees, omissão intencional de informações claras e suficientes, não prestação de informações acerca da taxa efetiva de juros e demais encargos cobrados, tudo isso pode dar ensejo à configuração do dolo ou malícia no campo da contratualidade, dando azo à imposição de danos punitivos.
\end{abstract}

Punitive damages constituem a quantia pecuniária, de valor variável, que visa punir o lesante por negligência, grave, quebra de contrato etc. e prevenir a prática novo ilícito futuro, estabelecida em separado, de eventual indenização compensatória a que possa fazer jus o ofendido (SERPA, 2011, p. 26; CORRÊA, 2006, p. 195; VAZ, 2009, p. 47).

Os punitive damages têm as seguintes funções: a) preventiva, visando a conscientização do ofensor e da sociedade da gravidade de determinados comportamentos, desestimulando a prática de novos ilícitos e promovendo um maior respeito aos direitos da personalidade, o bem estar social e o cumprimento das normas; b) punitiva, por constituírem uma sanção que condena a pagamentos de uma certa quantia pecuniária; c) dissuasória, por 
fazerem com que o lesante tome conhecimento de que sua grave conduta é indesejável jurídica e socialmente, sofrendo um processo pedagógico e desistindo de repetir a conduta reprovável.; d) educativa, por serem uma exceção aplicada em casos de grave e grosseira negligencia nas relações jurídicas contratuais ou sociais, indicando quais os comportamentos rechaçados pela sociedade (OWEN, 1994) ${ }^{1}$.

Em decisão do Tribunal de Justiça de Minas Gerais, o Desembargador Relator Tibúrcio Marques reconhece a função mista da reparação dos danos morais sob o seguinte fundamento:

Relativamente à mensuração dos danos morais, deve-se ressaltar que a reparação do dano moral tem função compensatória e punitiva. A primeira, compensatória, deve ser analisada sob os prismas da extensão do dano e das condições pessoais da vítima. $\mathrm{O}$ exame da extensão do dano leva em conta o bem jurídico lesado, como por exemplo a honra, a integridade psicofísica, etc. já as condições pessoais da vítima é o critério que pesquisa a situação do ofendido antes de depois da lesão. A finalidade punitiva, por sua vez, tem caráter pedagógico e preventivo, motivo pelo qual visa desestimular o ofensor a reiterar a conduta ilícita. Nesse ponto, observa-se a condição econômica do ofensor e o grau de culpa do agente (TJMG, Ap. Cível n. 10440.12.00/099-4/001-15 Câmara Cível, 17.5.2013).

De outro lado, em ação de reparação de danos por cobrança abusiva, que tramitou na Comarca de Passo Fundo, estado do Rio Grande do Sul. A magistrada de $1^{\mathrm{a}}$ instância aplicou o instituto dos punitive damages exatamente como no sistema norte-americano. A sentença condenou a empresa requerida a $\mathrm{R} \$ 30.000,00$ (trinta mil reais) a título de danos morais e a $\mathrm{R} \$$ 200.000,00 (duzentos mil reais) a título de indenização punitiva (Processo n. 1.11.0015236-0, $1^{\mathrm{o}}$ Juizado da $4^{\mathrm{a}}$ Vara Cível, juiz, Luciana B. Tieppo. A condenação fundou-se no seguinte argumento:

Por outro lado, considerando todos os fatos acima expostos, mormente a insistência da demanda em cobrar dos consumidores serviços não contratados, entendo que deve ser aplicado ao caso, também, a função punitiva da responsabilidade civil, a fim de punir a conduta ilegal da demandada, a qual não pode ser ignorada pelo Judiciário em razão da grave lesão causada à coletividade. (...) Assim, certo é que a conduta da demandada foi por demais grave e é contrária ao interesse de toda a sociedade, assim como à boa-fé, lealdade e todos os deveres principais e acessórios que regem as relações contratuais. Evidente que tal conduta não pode ser aceita, pois,

\footnotetext{
${ }^{1}$ ELLIS (1982, p. 3) entende que visa punir o réu, impedir que o réu repita a ofensa, dissuadir outros de cometerem delito; preservação da paz; indução de aplicação do direito privado; compensar vítimas por prejuízos que não seriam indenizáveis; pagar honorários advocatícios. Mas conclui que duplo será o propósito: punir infrator, além da sanção a título de dano compensatório; impor esse prejuízo ao ofensor; promoveria eficiência mediante dissuasão da má conduta de criação de prejuízos.
} 


\section{“PUNITIVE DAMAGES” DO “COMMON LAW" NAS INDENIZAÇÕES POR DANO EXTRAPATRIMONIAL CAUSADO A CONSUMIDOR: UMA POSSIBILIDADE JURÍDICA NO \\ DIREITO BRASILEIRO}

repito, prejudicial a toda sociedade, e deve ser reprimida pelo direito, mormente em se considerando antes de qualquer coisa o dever geral de conduta, base de toda a responsabilidade civil, de não causar dano a outrem, non neminem laedere, vindo do Direito Romano e, ao que parece, esquecido na sociedade atual, que visa a obtenção de lucros cada vez maiores, em prejuízo da parte economicamente mais fraca e vulnerável. Assim, tenho por bem, levando em conta os lucros auferidos pela demandada, condenar a mesma a pagar a autora indenização ante a função punitiva da responsabilidade civil, no valor equivalente a $\mathrm{R} \$ 200.000,00$ (duzentos mil reais).

A sentença foi reformada pelo Tribunal de Justiça do Rio Grande do Sul através da $10^{\text {a }}$ Câmara Cível que excluiu a indenização punitiva da condenação:

(...) SENTENÇA ULTRA PETITA. CONDENAÇÃO AO PAGAMENTO DE PUNITIVE DAMAGES. EXCESSO EXTIRPADO. É cediço que, em atenção ao princípio da adstrição, preconizado nos artigos 128 e 460 do CPC, há limitação imposta à prestação jurisdicional, devendo o magistrado, ao proferir a sentença, ater-se aos estritos termos em que deduzidos a causa de pedir e o pedido. Viável a extirpação do excesso cometido, no que tange à concessão de indenização pela função punitiva da responsabilidade civil, quando o pedido foi apenas de reparação de danos morais, não havendo falar em desconstituição in totum da sentença.

O reconhecimento da função punitiva não deve trazer em seu bojo uma indenização supervalorizada, mas sim a majoração no quantum indenizatório.

Pressupostos para aplicação dos punitive damages podem ser: A) objetivos tais como a) ocorrência de um ato ilícito por descumprimento de um dever legal ou contratual (havendo abuso, desvio da boa-fé objetiva, opressão, malícia) (SIMPSON, 1959, p. 284); b) existência de um prejuízo substancial e B) subjetivo: grau de reprovabilidade de conduta ou estado de espírito do ofensor dotado de intenção dolosa, negligência, malícia e temeridade significativas.

A indenização punitiva contribuirá para a manutenção do equilíbrio das relações de consumo e para a defesa do contratante (consumidor) em posição de inferioridade reconstruindo integralmente o patrimônio da vítima do dano.

Deve-se levar em conta as circunstâncias do fato e a sua repercussão e exiquibilidade do encargo a ser suportado pelo devedor (JTJRS, 163:261). A avaliação do quantum do dano moral não pode ser um simples cálculo matemático-econômico, havendo necessidade de o juiz seguir um critério justo $(R T, 741: 357)$.

Para Nehemias D. de Melo, a verba indenizatória, a título de dano moral deveria ser fixada com base em três parâmetros: caráter compensatório para a vítima, proporcionando lhe alegria, compensando a agressão sofrida; caráter punitivo e dissuassório para o causador 
do dano, demonstrando que sua conduta é reprovável juridicamente, evitando que reincida no ilícito; e o caráter exemplar e pedagógico para a sociedade, dando certeza de que o comportamento lesivo será reprimido judicialmente (ANDRADE, 2006, pp. 261-277; MELO, 79:56-70).

Com base nesse trinômio, o órgão judicante poderia adicionar um plus como advertência a todos de que a sociedade não acata o ilícito e o reprime. Tal plus condenatório iria para entidades de benemerência, assistenciais, religiosas, filantrópicas, de pesquisa, de apoio à criança ou ao idoso etc. Diferente dos EUA, onde vige o exemplary damages, pelo qual a vítima é quem recebe daquele plus, outorgado a título de condenação penal.

De fato, mesmo diante dessa dupla função de punição e dissuasão ou prevenção, não há como confundir-se punitive damages, com a indenização por danos morais na tradição romanística, conquanto esta também desempenhe sabidamente função punitiva e preventiva. A diferença bem óbvia é que os punitive damages não detêm, nunca, também uma função compensatória e satisfativa, eis que simplesmente se constituem num plus, numa soma adicional, em relação à própria compensação de danos patrimoniais ou morais, isto é, aos danos compensatórios (compensatory damages).

O sistema de punitive damages funciona como um poderoso esquema de conformação social de comportamento e, em consequência, de moralização da ordem econômica, na expressão de Carval, corporificando um controle difuso de quaisquer vítimas contra quaisquer ofensores na seara das relações privado-econômicas, especialmente, punindo retrospectivamente e prevenindo prospectivamente.

Trata-se, certamente, de uma punição dentro da responsabilidade civil no sistema do common law, mas que conta igualmente com o instrumental propósito de inibir novos mas comportamentos idênticos. Os danos punitivos não podem deixar de desempenhar no direito brasileiro as mesmas funções de punição (punishment), isto é, de censura, sanção ou pena privativa ao ato violador, e de dissuasão ou prevenção (deterrence), a fim de que comportamento idênticos não sejam repetidos.

Na Argentina, em 7 de abril de 2008, foi a ideia de dano punitivo introduzida pela Ley de Defensa del Consumidor de la Argentina (Ley n. 24.240) o art. 52 bis, com a seguinte redação: 


\section{“PUNITIVE DAMAGES” DO “COMMON LAW" NAS INDENIZAÇÕES POR DANO EXTRAPATRIMONIAL CAUSADO A CONSUMIDOR: UMA POSSIBILIDADE JURÍDICA NO \\ DIREITO BRASILEIRO}

Art. 52 bis: Dano Punitivo. Ao fornecedor que não cumpra suas obrigações legais ou contratuais com o consumidor, a pedido da vítima, o juiz poderá aplicar uma multa civil em favor do consumidor, que se graduará de acordo com a gravidade do fato e demais circunstâncias do caso, independentemente de outras indenizações que correspondam. Quando mais de um fornecedor seja responsável pelo descumprimento, responderão todos solidariamente ante o consumidor, sem prejuízo das ações de regresso que lhes correspondam. A sanção civil que se imponha poderá superar o máximo da sanção de multa prevista no artigo 47, alínea b) desta Lei (...) Art. 47. Sanções. Verificada a existência da infração, aqueles que cometeram estarão sujeitos às seguintes sanções, que podem ser aplicadas independentemente ou em conjunto, como resultante das circunstâncias: (...) b) Multa em cem pesos (\$100) para cinco milhões de pesos (U\$ 5.000,000).

Com isso há, ensina Wladimir A. M. Falcão Cunha (CUNHA, 2012, pp. 94, 100, 116, 120 e 167),

no direito privado argentino os danos punitivos, para as hipóteses de danos pelo não cumprimento de obrigações legais ou contratuais, pelo que o juiz poderá aplicar uma multa civil em favor do consumidor e não em favor do fundo público. O quantum dessa multa punitiva se graduará pela gravidade do fato e demais circunstâncias do caso, o que faz crer que a doutrina e jurisprudência argentinas reservarão tal instituto para situações efetivamente graves de má conduta, muito embora há de perceber que o artigo não especificou quaisquer caracteres negativos da conduta do ofensor como requisito para a aplicação do instituto.

Nossos juízes e tribunais vêm dando guarida à reparabilidade dos danos morais $(R F, \quad 257: 221,250: 307,244: 101,245: 249,135: 75,43: 341,212: 236 ; 88:: 443$, 130:138, 221:200, 110:207, 31:259, 94:478, 169:260, 69:98, 93: 528, 45: 265; RTJ $39: 38,41: 844,72: 385 ; R T, 220: 474,198: 151,181: 312,8: 181,11: 35,30: 335$, $167: 335,177: 263,181: 312$, 198:152, 175:290, 224:252, 379: 168, 580: 152, 583:83, 602: 180, 616:195 , 781:232, 802:267, 814:250, 789: 278; AJ, 111:280, 99:238; Súmula 370 do STJ), inclusive a pessoa jurídica, havendo violação a seu nome, imagem e reputação (STJ, Súmula 227).

E pelo $\S 2^{\circ}$ a ser acrescentado, pelo PL n. 699/2011, ao art. 944, “a reparação do dano moral deve constituir-se em compensação ao lesado e desestímulo ao lesante". Tal alteração foi proposta porque:

O dispositivo é insuficiente, segundo nos alertou Regina Beatriz Tavares da Silva, já que seu caput se adapta somente ao dano material e não está adequado ao dano moral. O critério para a fixação do dano material é o cálculo de tudo aquilo que o lesado deixou de lucrar e do que efetivamente perdeu. $O$ critério da extensão do dano aplica-se 
perfeitamente à reparação do dano material-que tem caráter ressarcitório. No entanto, na reparação do dano não há ressarcimento, já que é praticamente impossível restaurar o bem lesado, que, via de regra, tem caráter imaterial. $\mathrm{O}$ dano moral resulta, na maior parte das vezes, da violação a um direito da personalidade: vida, integridade física, honra, liberdade etc. Por conseguinte, não basta estipular que a reparação mede-se pela extensão do dano. Os dois critérios que devem ser utilizados para a fixação do dano moral são a compensação lesado e o desestímulo ao lesante, inibindo comportamentos lesivos. Inserem-se neste contexto fatores subjetivos e objetivos, relacionados às pessoas envolvidas, como a análise do grau da culpa do lesante, de eventual participação do lesado no evento danoso, da situação econômica das partes e da proporcionalidade ao proveito obtido com o ilícito. Em suma, a reparação do dano moral deve ter em vista possibilitar ao lesado uma satisfação compensatória e, de outro lado, exercer função de desestímulo a novas práticas lesivas, de modo a 'inibir comporta mentos antissociais do lesante ou de qualquer outro membro da sociedade', traduzindo-se em 'montante que represente advertência ao lesante e à sociedade de que não se aceita o comportamento assumido, ou o evento lesivo'. Ao juiz devem ser conferidos amplos poderes, tanto na definição da forma como da extensão da reparação cabível, mas certos parâmetros devem servir-lhe de norte firme e seguro, sendo estabelecidos em lei, inclusive para que se evite, definitivamente, o estabelecimento de indenizações simbólicas, que nada compensam à vítima e somente servem de estímulo ao agressor.

Entretanto, houve rejeição da proposta pelo Parecer Vicente Arruda, nestes termos:

A doutrina define o dano moral de várias formas. Todas as definições, entretanto, são coincidentes no que diz respeito a ser referente ao dano de bens não patrimoniais ou não econômicos do lesado. Em nenhum lugar a indenização por dano moral é relacionada à pena. É justamente esse caráter de pena que ora se pretende dar quando o PL diz: 'adequado desestímulo ao lesante'. Além do mais confere-se ao juiz um arbítrio perigoso porque não delimita a fronteira entre o dano efetivo e o adequado desestímulo ao cometimento de futuros atos ilícitos. Cria também um duplo critério de avaliação da indenização. O critério para cálculo do valor da indenização do dano, tanto para o material quanto para o moral, deve ser o da sua extensão.

A reparação do dano moral não tem apenas a natureza penal, visto que envolve uma satisfação à vítima, representando uma compensação ante a impossibilidade de se estabelecer perfeita equivalência entre o dano e o ressarcimento. A reparação pecuniária do dano moral é um misto de pena e de satisfação compensatória. Não se pode negar sua função: a) penal, constituindo uma sanção imposta ao ofensor, visando a diminuição de seu patrimônio, pela indenização paga ao ofendido, visto que o 


\section{“PUNITIVE DAMAGES” DO “COMMON LAW" NAS INDENIZAÇÕES POR DANO EXTRAPATRIMONIAL CAUSADO A CONSUMIDOR: UMA POSSIBILIDADE JURÍDICA NO \\ DIREITO BRASILEIRO}

be m jurídico da pessoa - integridade física, moral e intelectual — no poderá ser violado impunemente, subtraindo-se o seu ofensor às consequências de seu ato por não serem reparáveis; e b) satisfatória ou compensatória, pois como dano moral constitui um menoscabo a interesses jurídicos extrapatrimoniais, provocando sentimentos que não têm preço, a reparação pecuniária visa proporcionar ao prejudicado uma satisfação que atenue a ofensa causada. Não se trata de uma indenização de sua dor, da perda de sua tranquilidade ou prazer de viver, mas de uma compensação pelo dano e injustiça que sofreu, suscetível de proporcionar uma vantagem ao ofendido, pois ele poderá, com a soma de dinheiro recebida, procurar atender às satisfações materiais ou ideais que repute convenientes, atenuando, assim, em parte, seu sofrimento.

Fácil é denotar que o dinheiro não terá na reparação do dano moral uma função de equivalência própria do ressarcimento do dano patrimonial, mas um caráter concomitantemente satisfatório para a vítima e punitivo para o lesante, sob uma perspectiva funcional. A reparação do dano moral cumpre, portanto, uma função de justiça corretiva ou sinalagmática, por conjugar, de uma só vez, a natureza satisfatória da indenização do dano moral para o lesado, tendo em vista o bem jurídico danificado, sua posição social, a repercussão do agravo em sua vida privada e social e a natureza penal da reparação para o causador do dano, atendendo a sua situação econômica, a sua intenção de lesar (dolo ou culpa), a sua imputabilidade etc. (DINIZ, 2017, pp. 127-132; LARENZ, 1959, pp. 642-643; MORELLO, 27: 342 e ss; SILVA, 1966 pp. 424 e ss; ZANNONI, 1982, p. 265).

Contudo, observa Claudia Lima Marques (MARQUES, 2005, p. 15) que a função punitiva da responsabilidade civil efetivamente pode contribuir para assegurar a confiança no direito como um todo, em sua noção de princípio jurídico máximo, mas também, a confiança mais específica no outro, seja nos contratos, seja em relações delituais:

(...) os danos causados pela mass media e contra o consumidor têm em comum a necessidade de exercer esta função pedagógica (prevenção de casos semelhantes), satisfatória e exemplar, evitando a impunidade de condutas abusivas, de forma a assegurar a confiança no direito e sancionando as práticas comerciais de tal forma que não haja mais lucro em danear o mais fraco.

Nítida é a importância da aplicação dos punitive damages nas relações de consumo, não só pela função punitiva na reparação do dano extrapatrimonial como também pela sua 
função de law enforcement, ou seja, de incitar o particular a cumprir a lei e pela ideia de private attorney general, isto é, de motivar a vítima de mover ações judiciais, incrementando a punição e dissuasão do mau comportamento (CUNHA, 2012, pp. 96 e 106).

\section{POSSIBILIDADE JURÍDICA DE APLICAÇÃO DA INDENIZAÇÃo PUNITIVA NO DIREITO DO CONSUMIDOR BRASILEIRO}

Em regra, para se admitir a possibilidade de indenização punitiva em caso de lesão extrapatrimonial seria necessária a existência de previsão legislativa específica, indicativa de restrições para limitar a discricionariedade judicial e evitar punição indiscriminada.

Os argumentos pelos quais os danos punitivos não devem ser aplicados no Brasil são: possibilidade de indenização que constituam fontes de lucros; insegurança jurídica oriunda da imprevisibilidade das condenações; inibição da mercantilização de relações sociais; proibição de enriquecimento sem causa (BIAZZI, 2014, p. 160).

Observa Maria Celina B. de Novaes (MORAES, 2003, p. 33):

Por outro lado, a intenção de punir o ofensor obriga, ainda, que se avalie o grau de culpa, geralmente irrelevante para a indenização do dano material, e que se apreciem as condições econômicas do agente causador do dano (..) Tentando cumprir funções de natureza antagônica, o resultado não poderia deixar de ser paradoxal: deve-se punir o ofensor, mas não a ponto de enriquecer a vítima. No entanto, é dedução lógica obrigatória que, sob o ponto de vista econômico, a vítima sairá, nesses casos, "enriquecida", na medida em que estará recebendo necessariamente mais do que a compensação do dano demandaria. (...) Nos Estados Unidos, de onde os chamados "danos punitivos" foram importados, não há qualquer preocupação com o enriquecimento da vítima, o qual, antes é pressuposto.

Por isso será mister que haja uma limitação da indenização em cada caso concreto, tendo por parâmetro a razoabilidade e a proporcionalidade, competindo ao órgão judicante estabelecer os limites dos punitive damages.

A omissão legal, em nosso país, no que atina aos punitive damages, não obsta sua aplicação nas relações consumeristas, por força do disposto nos arts. $4^{\circ}$ e $5^{\circ}$, da LINDB, que resolvem questões de lacuna.

Os punitive damages, além de ressarcir o prejuízo causado ao consumidor (lesado), tem por escopo punir o lesante mediante pagamento de uma alta indenização pecuniária, 


\section{“PUNITIVE DAMAGES” DO “COMMON LAW" NAS INDENIZAÇÕES POR DANO EXTRAPATRIMONIAL CAUSADO A CONSUMIDOR: UMA POSSIBILIDADE JURÍDICA NO \\ DIREITO BRASILEIRO}

fixada por meio de arbitramento, a fim de evitar que haja reincidência daquele ato ilícito por parte do infrator e da sociedade.

A violação de direito da personalidade (CC, art. 12), por si só, justificaria a incidência dos danos punitivos, desde que seja considerada, pelo órgão judicante, suficiente para atender os princípios da prevenção e da punição.

A admissibilidade de aplicação dos punitive damages no Brasil, deve ter por parâmetro a ideia de que não são instrumentos de punir por punir, mas de correção social de condutas privadas e de reequilíbrio mediante prevenção das relações econômicas marcadas pela vulnerabilidade das relações consumeristas (CUNHA, 2012, p. 179).

É preciso admiti-la, como tem feito o ativismo judicial, atendendo interesse de consumidor contra grandes grupos econômicos, que, visando o lucro, lesam seus direitos (SOUZA, 2013, p. 189).

Segundo Raquel Grellet Pereira Bernardi, a Constituição Federal possui princípios e fundamentos suficientes para a adoção da função punitiva, entre eles, a dignidade humana, especialmente ofendida pela lesão aos direitos da personalidade. Aduz a autora que, "para a proteção e promoção do princípio da dignidade humana e dos direitos da personalidade, impõe-se o emprego não apenas ferramental previsto pelas normas infraconstitucionais, mas de todos os meios hábeis ou necessários para o alcance desse desiderato" (BERNARDI, 2012, pp. 191-193). Afirma, ainda que as leis penais não abarcam todas as formas de atentado à direitos da personalidade.

Pela $\mathrm{CF} / 88$ art. $1^{\circ}$, III, a dignidade da pessoa humana é considerada um dos fundamentos da República Federativa do Brasil, sendo "um valor supremo que atrai o conteúdo de todos os direitos fundamentais do homem" (SILVA, 1999, p. 40) que garante o mínimo existencial e pleno desenvolvimento da personalidade (BARCELLOS, 2008, p. 288). Por tal razão seria um dos parâmetros que tornaria possível a aplicação do dano punitivo no Brasil.

Observa Raquel G. P. Bernardi (BERNARDI, 2012, pp. 191-193)

Considerando os princípios constitucionais da dignidade da pessoa humana e da igualdade, afirma-se que a inserção dos danos punitivos no direito brasileiro atende a ambos, na medida em que proporcionará às vítimas lesadas por hipossuficientes a garantia de ressarcimento de seu patrimônio material e/ou moral, o que corresponde à consecução plena do princípio da dignidade humana e, ao mesmo tempo, a igualdade de tratamento a todos os 
lesados, independentemente de seu autor se tratar de indivíduo capaz de garantir o ressarcimento do patrimônio da vítima ou de hipossuficiente.

A ideia de se dar caráter de pena à indenização por dano moral justificar-se-á para proteger os direitos da personalidade e a dignidade da pessoa em casos especiais, em que não há outro instrumento que atende a esse objetivo.

Os punitive damages justificam-se, também, não só pelo princípio da eticidade ou da boa-fé objetiva, que norteia do CC de 2002, abrangendo a participação dos valores éticos no ordenamento jurídico, como também pelo princípio da socialidade (REALE, 2005, pp. 37 e $38)$.

Apesar de o princípio da confiança do consumidor seja complementar ao princípio da boa-fé objetiva, como uma resposta à uma crise dos contratos consumeristas e a uma crise geral de confiança no direito, Cláudia Lima Marques o considera como um princípio imanente a todo o direito, e não somente às relações contratuais; sendo, por tal razão, um dos fundamentos para a aplicação dos punitive damages nas relações de consumo (MARQUES, 2011, p. 27; CUNHA, 2012, p. 145).

Além disso, uma análise a contrário sensu do art. 944, §único, do CC, que permite a redução equitativa da indenização levaria a conclusão, por meio de interpretação extensiva, que, em caso de negligência grave, dolo, fraude ou malícia, o órgão judicante poderia aumentar a pena, apesar de o CC ter repelido a ideia de indenização punitiva, aplicando-se o art. $5^{\circ}$, da LINDB, ante o comportamento particularmente reprovável (CARVALHO FILHO, 2003, p. 71).

Urge lembrar, ainda, que pela $\mathrm{CF} / 88$, art. $5^{\circ}, \mathrm{V}$, há previsão legal do dever de ressarcir dano extrapatrimonial, que é oriundo de uma violação a direitos da personalidade, independentemente do sofrimento causado ao titular.

A responsabilidade civil visa proteger a vítima, impondo ao ofensor o dever de reparar o dano, pagando um quantum indenizatório, compensando o lesão pelo prejuízo.

É preciso desestimular o ofensor e a sociedade para a prática de atos semelhantes, daí a importância dos punitive damages, por fazer com que a responsabilidade civil tenha, além de função reparadora e compensatória, a punitiva. Sendo o ofensor condenado a pagar um valor considerável a título de indenização, fará com que ele e a sociedade tomem consciência de que o ato praticado não é tolerado pelo Judiciário, ficando sem coragem para cometer, futuramente, novos danos similares. 


\section{“PUNITIVE DAMAGES” DO “COMMON LAW" NAS INDENIZAÇÕES POR DANO EXTRAPATRIMONIAL CAUSADO A CONSUMIDOR: UMA POSSIBILIDADE JURÍDICA NO \\ DIREITO BRASILEIRO}

Fácil é perceber que os punitive damages, além do caráter punitivo, possuem o preventivo (desestímulo para cometer ato ilícito) e o retributivo (reparação satisfatória do ofendido, demonstrando a ele e a toda sociedade que o prejuízo foi ressarcido integralmente) (VIEGAS; GUEDES, 101: 90-91).

Como os fornecedores procuram auferir grandes lucros, ferindo direitos do consumidor, reparando-os mediante pagamento de quantias que não afetam seu patrimônio, com isso os consumidores, ante a impunidade do fornecedor, não estão ingressando em juízo. Daí a importância da aplicação dos punitive damages para que haja uma integral reparação do dano moral sofrido pelo consumidor, sendo a prática ilícita grave e reiterada.

Pela CF/88, art. $5^{\circ}, \mathrm{XXXII}$, o Estado tem o dever de proteger o consumidor, logo não basta a mera reparação do prejuízo, sendo imprescindível a prevenção de novas práticas ilícitas similares por parte do fornecedor.

Dever-se-á também não olvidar que o art. 170 da CF possibilita os punitive damages ao preservar que a defesa do consumidor é um princípio econômico, sendo inadmissível lucro oriundo de atividade danosa ao consumidor (VIEGAS; GUEDES, 101: 96-97).

Quando da aplicação do direito a um fato concreto, é preciso correlacionar as normas entre si, bem como o subsistema de valores e de fatos a ele correspondente, não devendo o órgão judicante ter um critério puramente normativo; deve, sim dar lugar uma compreensão dos sistemas normativos em relação a fatos e aos valores que o informam.

$\mathrm{Na}$ verdade, o juiz se vê na dificuldade de decidir certas hipóteses, por não encontrar nas normas descritas no sistema normativo, os instrumentos indispensáveis para solucioná-los (RAÓ, 1952, pp. 89). O que interessa saber não é se essas condutas estão proibidas ou permitidas por um determinado sistema normativo, mas sim saber se elas podem ser solucionadas pelos demais subsistemas. Ante a necessidade de adaptar a finalidade da norma ás exigências sociais, o magistrado aplicará o art. $5^{\circ}$ da LINDB, visto que não deverá ficar alheio ás exigências da vida, porque o fim da norma não deve ser a imobilização da vida, e sim, manter contato íntimo com ela, segui-la em sua evolução e a ela adaptar-se. O sentido normativo requer a captação dos fins para os quais se elaborou a norma, exigindo a concepção do direito como um sistema, o apelo ás regras da técnica lógica válidas para séries definidas de casos, e a presença de certos princípios que se aplicam àquelas séries de casos, como o da boafé, o da eficiência da justiça, o do respeito aos direitos da personalidade e da dignidade humana, o da igualdade perante a lei etc. (FERRAZ JR, 1977, p. 79; FERRAZ JR, 1978, pp. 
152-154; ENGISCH, 1964, pp. 108-109 e 115-210; LARENZ, 1966, pp. 262-270; MAXIMILIANO, 1965, pp. 163-168; DINIZ, 2014, pp. 460-461).

$\mathrm{O}$ art. $5^{\circ}$ da LINDB e as normas CF (arts. $1^{\circ}$, III; $5^{\circ}$, V e XXXII, 170) possibilitam que o órgão judicante procure adequação do direito à sua finalidade social, atendendo às valorações vigentes na sociedade, aplicando, se necessário for, as punitive damages nas relações de consumo.

$\mathrm{O}$ ativismo judicial vem, portanto, procurando suprir as deficiências da lei e decisões judiciais, com o decorrer dos tempos, acabam, às vezes, se sobrepondo à letra escrita, porque não só atualiza o entendimento da lei, atendendo aos reclamos da necessidade do momento do julgamento, como também preenche lacunas.

Assim sendo, a ordem jurídica vem recebendo inclusões de instituições próprias de país de commom law, como os punitive damages por ato do Poder Judiciário que, sendo uma operação axiológica, integrativa, possui índole político-jurídica. A função jurisdicional é ativa, contendo uma dimensão nitidamente criadora, tendo por escopo reavaliar a axiologia que informa a ordem jurídico-positiva.

$\mathrm{Na}$ quantificação do dano punitivo dever-se-á levar, tendo por base a proporcionalidade, a razoabilidade e a adequação, em consideração: a) a pessoa do ofensor (modo como agiu ao ferir direitos de outrem, p. ex. se fez uso de fraude, malícia, simulação; sua consciência dos riscos, grau de culpa ou reprovabilidade de sua conduta; suas condições sócio-econômicas para evitar que não só haja lucro e que a condenação não o leve à insolvência ou falência, mas também que sinta economicamente o peso do quantum indenizatório, desistindo de auferir lucro ilicitamente e perdendo o estímulo de praticar infrações similares.

a) as condições pessoais (grau de maturidade, vulnerabilidade, estado físico e psíquico e sociais da vítima, para que a reparação seja isonômica; b) a relevância do dano moral causado a direito da personalidade do lesado; c) a extensão do dano sofrido; d) o grau de exteriorização do dano; e) o tempo de exposição a esse dano; f) a reiteração de condutas similares; g) a obtenção de lucro com a conduta delituosa; h) discrepância considerável entre o grau de culpa do ofensor e o dano causado ou entre os efeitos imputáveis à conduta do agente e o seu comportamento; i) a eventual existência de condenação com função punitiva, em outros danos; j) a proporcionalidade entre o quantum indenizatório e o prejuízo, evitando 


\section{“PUNITIVE DAMAGES” DO “COMMON LAW" NAS INDENIZAÇÕES POR DANO EXTRAPATRIMONIAL CAUSADO A CONSUMIDOR: UMA POSSIBILIDADE JURÍDICA NO \\ DIREITO BRASILEIRO}

enriquecimento sem causa da vítima; k) a análise de punições em casos semelhantes (CUNHA, 2012, p. 188 e 189).

Se o órgão judicante ao estabelecer a sanção à lesão de direitos da personalidade, pretender além da compensação do dano sofrido pela vítima, desestimular o lesante e a sociedade à prática do ato ilícito poderá haver desequilíbrio entre a condenação do ofensor e a condição patrimonial preexistente da vítima.

Para solucionar isso os juristas tem encontrado saída na destinação das verbas indenizatórias a fundo beneficente, de entidades assistenciais ou do Estado atendendo à solidariedade, a justiça distributiva e o respeito à dignidade humana (BIAZI, 2014, pp. 146149; MELLO, v, 26, n. 275, p. 118) $)^{2}$ É preciso que tal fundo seja formado pelos valores oriundos de danos punitivos aplicados aqueles que, tendo lesado dolosamente outrem, possuem capacidade econômica. A vítima seria indenizada integralmente e uma parcela do patrimônio do autor seria destinado ao pagamento dos danos punitivos, cujo valor seria revertido à reparação de danos experimentados por vítimas lesadas por alguém economicamente impossibilitado de pagar a indenização.

A aplicação do dano punitivo é possível, como dissemos alhures, mediante ativismo judicial ao aplicar princípios constitucionais da dignidade da pessoa humana, da igualdade, da proporcionalidade e da razoabilidade. E os valores pagos iriam para o fundo, que garantiria ressarcimento de prejuízos de vítimas de ofensores hipossuficientes.

Logo, se o dano for suportado por uma pessoa específica ou por um grupo de indivíduos (p. ex. sócios de uma empresa), o lesado deverá receber (dentro da filosofia do private attorney general) o arbitrado da indenização punitiva, que não deverá ir para um fundo público como o Fundo de Defesa de Direitos Difusos previsto na Lei n. 7.347/1985 (LACP), aplicável aos danos coletivos nas relações de consumo (CDC, art. 100, § único). Mas há possibilidade de se aplicar o art. 100, do CDC, isto é, a reversão ao fundo da LACP, se após um ano não houver habilitação de interessados em número compatível com a gravidade do dano.

\section{CONCLUSÃO}

\footnotetext{
${ }^{2}$ Consulte: sentença proferida na 6a Vara Cível de São Paulo. Processo n ${ }^{\circ}$ 0028224.49.2006.403.6100.
} 
O consumidor ao adquirir um produto ou contratar um serviço espera que tenha boa qualidade, mas o fornecedor, buscando lucro, faz com que haja, num menor tempo possível, uma, maior quantidade de produtos e serviços e com isso coloca à disposição do mercado de produtos e serviços viciados ou inferiores às expectativas do consumidor final. Consequentemente, o consumidor vê seus direitos violados pelo fornecedor, que vende produtos defeituosos ou fornece serviços não solicitados, por meio de propagandas enganosas. Ante a vulnerabilidade do consumidor, a lei lhe dá instrumentos eficazes para fazer valer seus direitos e reparar o prejuízo sofrido, mas, apesar, da condenação do ofensor à reparação dos danos, paira no ar uma impunidade, que não coíbe a reiteração da prática ilegal. Por tal razão seria preciso que houvesse, além da indenização para reparação do dano, uma sanção que punisse o ofensor. Assim, o ofensor e a sociedade empresária perderiam a motivação para cometer delito similar arraigando na sociedade a ideia de dano, diminuindo as demandas consumeristas.

O ordenamento jurídico brasileiro não prevê os punitive damages. Para atender os princípios da dignidade humana, se se entender que há necessidade de uma punição mais severa, para desestimular o ofensor a novas agressões, apesar de haver a possibilidade de enriquecimento sem causa (CC, art. 884; STJ, AGRg-AG 850.273/BA, 4 ${ }^{\text {a }}$ T. Rel. Min Homildo A. de Mello Castro, 24.8.2010), de aplicação de pena sem prévia cominação legal $\left(\mathrm{CF}\right.$, art. $5^{\circ}, \mathrm{XXXIX)}$ e de arbitramento de indenização superior à extensão do dano, dever-se-á admitir os punitive damages. A indenização punitiva supre lacuna do CDC que não contêm norma que coíba a reiteração de atos ilícitos contra o consumidor.

Daí a importância da aplicação pelo Judiciário da teoria dos punitive damages do sistema de commom law, impondo indenizações suscetíveis de reparar o dano, compensando o prejuízo sofrido pelo lesado, de punir o ofensor e de impedir novas práticas ilícitas, quebrando a sensação de impunidade das sociedades empresárias e equilibrando a relação consumerista.

Assim, ante o indício de que a sanção imposta ao fornecedor que causou dano ao consumidor, não está protegendo seu direito, por não coibir a reiteração de ato lesivo semelhante, justificada está a apuração de indenização punitiva pelo Poder Judiciário diante do disposto na $\mathrm{CF}$, art. $1^{\circ}, \mathrm{III} ; 5^{\circ}, \mathrm{V}, \mathrm{XXXII}, 170$ e na LINDB, arts. $4^{\circ}$ e $5^{\circ}$ e, por ser meio eficaz para impedir constante desrespeito aos direitos do consumidor (VIEGAS; GUEDES, 101: 100101). 


\section{“PUNITIVE DAMAGES” DO “COMMON LAW" NAS INDENIZAÇÕES POR DANO EXTRAPATRIMONIAL CAUSADO A CONSUMIDOR: UMA POSSIBILIDADE JURÍDICA NO \\ DIREITO BRASILEIRO}

Dever-se-á admitir os punitive damages (também designados vindictive damages, exemplary damages, punitory damages, smart money) no direito brasileiro diante da insuficiência da teoria compensatória como critério para a configuração da responsabilidade civil, por ser um instrumento de controle dos comportamentos privados nas relações jurídicas, em que há vulnerabilidade entre as partes, tutelando a pessoa e sua personalidade, uma vez que a reparação integral do dano é um direito fundamental, daí a vinculação imediata do órgão judicante para que haja eficácia desse direito e a amplitude de sua discricionariedade em sua concretização (CANARIS, 2009, pp. 28 e ss, 91).

$\mathrm{O}$ instituto dos punitive damages seria, portanto, uma forma de reparação do dano extrapatrimonial nas relações de consumo e de prevenção para que haja diminuição da sua incidência, protegendo os direitos do consumidor, auxiliando a equilibrar a relação vulnerável existente entre consumidor e fornecedor. É mediante a censura, repreensão e punição econômica, que os danos punitivos exercem prevenção especial dirigida ao autor da conduta delituosa e a prevenção geral voltada e todos os membros da sociedade, incitando o cumprimento da norma legal ou do contrato (CUNHA, 2012, p. 167).

Os punitive damages para a indenização de danos extrapatrimoniais são de grande valia para a tutela da dignidade da pessoa humana, de seus direitos fundamentais e de seus direitos da personalidade, possibilitando o controle sócio-econômico difuso das condutas privadas, o equilíbrio das relações de consumo com a ordem econômica (CUNHA, 2012, p. 155) e o resgate de valores éticos. Têm sido aplicados no ressarcimento do dano moral sem que haja separação entre os valores compensatórios e os punitivos em razão do caráter duplo da reparação da lesão extrapatrimonial que é compensatória ou reparadora do prejuízo sofrido pela vítima e punitiva, que penaliza o lesante.

A compensação, prevenção e punição podem ser consideradas como funções da responsabilidade civil.

O dano punitivo visa punir o lesante e dissuadi-lo, bem como os demais membros da comunidade, de repetir comportamento similar (BERNARDI, 2012, p. 116).

Os danos punitivos representam não só uma punição para o ofensor, que agiu maliciosa e intencionalmente, não sendo uma mera questão de indenização dos prejuízos sofridos pelo lesado, mas também um aviso para outros membros da sociedade de que o Judiciário não tolera agressão aos direitos da personalidade do consumidor. 
Com os punitive damages, ter-se-á reparação do dano como direito fundamental, tendo como norte o princípio do respeito à dignidade humana e o da isonomia, sendo que o fundo para a captação de recursos oriundos do pagamento do dano punitivo, similar ao fundo de defesa dos direitos difusos, poderá servir de garantia para indenização devida pelo ofensor sem recursos.

O Poder Judiciário vem, diante de omissões do legislativo e do executivo, exercendo sua função sócio-política, mediante interpretação extensiva e os recursos de integração, ao apresentar julgados que atingem de forma direta as relações sociais, dando origem ao ativismo judicial, que propõe maior flexibilidade na aplicação das normas jurídicas para atingir a certas finalidades consentâneas à consciência jurídica geral, fazendo uso de sua discricionariedade ao analisar, com flexibilidade interpretativa de forma criativa os textos legais.

Ante a ausência de normas e critérios para a quantificação dos danos punitivos, a discricionariedade judicial não é aleatória nem desmensurada por ficar limitada às peculiaridades de cada caso, considerando: a natureza e gravidade da ofensa; a posição social, política, profissional e familiar do ofendido; a intensidade do grau de culpa ou dolo do ofensor; o desestímulo à procura de meio de enriquecimento sem causa, a fim de que a indenização sirva de consolo para a vítima, possibilitando a reparação integral do prejuízo; e a não reincidência por parte do lesante e o nível de propagação da ofensa (TJES-Ap. Cível 035010111470-2ª Câm. Cível Rel. Des. Álvaro M. R. Bourguigon.

\section{BIBLIOGRAFIA}

AMARAL NETO, Francisco dos Santos. Responsabilidade civil-II. in Enciclopédia Saraiva do Direito, v. 65.

ANDRADE, André G. C.. Dano moral e indenização punitiva. Rio de Janeiro: Forense, 2006. BARCELLOS, Ana Paula de. Eficácia jurídica dos princípios constitucionais: o princípio da dignidade da pessoa humana. Rio de Janeiro, Renovar, 2008.

BENACCHIO, Marcelo. Responsabilidade civil preventiva. Informativo IASP, 98: 38-39.

BERNARDI, Raquel Grellet Pereira. Danos punitivos: eficácia isonômica do direito fundamental de reparação integral dos danos. Tese de doutorado. Pontifícia Universidade Católica de São Paulo - PUCSP, 2012. 


\section{“PUNITIVE DAMAGES” DO “COMMON LAW" NAS INDENIZAÇÕES POR DANO EXTRAPATRIMONIAL CAUSADO A CONSUMIDOR: UMA POSSIBILIDADE JURÍDICA NO \\ DIREITO BRASILEIRO}

BIAZI, Danielle Portugal de. Os fundamentos da indenização punitiva e sua aplicabilidade no direito brasileiro. Dissertação de mestrado. Pontifícia Universidade Católica de São Paulo PUCSP, 2014.

BITTAR, Eduardo C. B. Contribuições para a prática da consciência consumista acerca da construção dos direitos do consumidor. Estudos de direito do autor, direito da personalidade, direitos do consumidor e danos morais. Eduardo C.B. Bittar e Silmara J. Chinelato (coord.). Rio de Janeiro: Forense, 2002.

CANARIS, Claus-Wilhelm. Direitos fundamentais e direito privado. Coimbra: Almedina, 2009.

CARVALHO FILHO, Milton Paulo de. Indenizações por equidade no novo Código Civil. São Paulo: Atlas, 2003.

CORRÊA, André Gustavo. Dano moral e indenização punitiva. Rio de Janeiro: Forense, 2006. CUNHA, Wladimir X.M. F. Danos extrapatrimoniais e função punitiva. Tese de doutorado. Universidade de São Paulo - USP, 2012.

DIAS, José de Aguiar. Da responsabilidade civil. 6. ed. Rio de Janeiro: Forense, v. 1, 1979. DINIZ, Maria Helena. Compêndio de Introdução à Ciência do Direito. São Paulo: Saraiva, 2014.

DINIZ, Maria Helena. Conceito de norma jurídica como problema de essência. São Paulo: Saraiva, 1999.

DINIZ, Maria Helena. Curso de direito brasileiro. São Paulo, Saraiva, vol. 7, 2017.

ELLIS JR, Dorsey D. Fairness and efficiency in the law of punitive damages. $56 \mathrm{~S}$. Cal. $L$. Rev. 1 (1982).

ENGISCH. Introdução ao pensamento jurídico. Lisboa: Calouste Gulbenkian, 1964.

FERRAZ JR., Tércio Sampaio. A ciência do direito. São Paulo: Atlas, 1977.

FERRAZ JR., Tércio Sampaio. Função social da dogmática jurídica. São Paulo: RT, 1978. FILOMENO, José Geraldo Brito. Manual de direitos do consumidor. São Paulo: Atlas, 2001. FILOMENO, José Geraldo Brito. Tutela contratual no novo Código Civil em face do Código de Defesa do Consumidor. O Código e sua interdisciplinaridade. Belo Horizonte: Del Rey, 2004.

GOMES, Orlando. Obrigações. 4. ed. Rio de Janeiro: Forense, 1976.

LARENZ, Karl. Derecho de obligaciones. Revista de Derecho Privado, t. 2, 1959.

LARENZ, Karl. Metodologia de la ciência del derecho. Barcelona: Ariel, 1966. 
LIMA, Alvino. Da culpa ao risco. $R F, 83: 385$.

MARQUES, Claudia Lima. Prefácio, in Bruno Miragem, Responsabilidade civil de Imprensa por dano à honra. O novo CC e a Lei de Imprensa. Porto Alegre: Livraria dos Advogados, 2005.

MARQUES, Claudia Lima. Prefácio, in Marcos Dessaune, Desvio produtivo do consumidor. São Paulo: RT, 2011.

MARTON. Les fondements de la responsabilité civile. Paris, n. 97, 1938.

MAXIMILIANO, Carlos. Hermenêutica e aplicação do Direito. Rio de Janeiro: Freitas Bastos, 1965.

MELO, Diego L. M. do. Ainda sobre a função punitiva da reparação dos danos morais e a destinação de parte da indenização para entidade de fins sociais, art. 883, parágrafo único, do CC, de 2002. Revista de Direito Privado, São Paulo, v. 6.

MENDONÇA, Manoel Ignácio Carvalho de. Doutrina e prática das obrigações. 3 ed. Rio de Janeiro: Freitas Bastos, t. 2, 1938.

MORAES, Maria Celina Bodin de. Danos à pessoa humana: uma leitura civil-constitucional dos danos morais. Rio de Janeiro: Renovar, 2003.

MORELLO, Augusto M. Carácter ressarcitório e punitório del dano moral. En pro de uma posición funcional. JÁ, 27: 342 e ss.

OWEN, David G. Punitive damages in products liability litigation. Michigan Law Review, Vol. 74.

OWEN, David G. A punitive damages overview: functions, problems and reform. 39, VIII, Rev. 363 (1994).

PLANIOL, RIPERT E ESMEIN. Traité pratique de droit civilfrançais. Paris, LGDJ, 1952, v. 6 .

PONTES DE MIRANDA. Tratado de direito privado. Rio de Janeiro: Borsoi, t. 22, 1971.

RÁO, Vicente. O direito e a vida do direito. São Paulo: Max Limonad, 1952.

REALE, Miguel. História do novo Código Civil. São Paulo: RT, 2005.

SANDOVAL e PIZARRO. Los daños punitivos en el derecho argentino. Revista de Derecho Comercial, del Consumidor e de la Empresa, La Ley, n. 1, pp. 65-96, set. 2010.

SERPA, Pedro R e. Indenização punitiva. 2011.

SERPA LOPES. Curso de Direito Civil. 2. ed. Freitas Bastos, v. 5, 1962.

SILVA, José Afonso da. Curso de direito constitucional positivo. São Paulo: Malheiros, 1999. 


\section{“PUNITIVE DAMAGES” DO “COMMON LAW" NAS INDENIZAÇÕES POR DANO EXTRAPATRIMONIAL CAUSADO A CONSUMIDOR: UMA POSSIBILIDADE JURÍDICA NO \\ DIREITO BRASILEIRO}

SILVA, Wilson M. da. O dano moral e sua reparação. Rio de Janeiro: Forense, 1966.

SIMPSON, Laurence. Punitive damages for breach of contract. Ohio State Law Journal Columbus, 1959, vol. 20.

SOUZA, Wendell L. B. de. Danos morais no Brasil e o direito de empresa. Tese de doutorado. Pontifícia Universidade Católica de São Paulo - PUCSP, 2013.

STOCCO, Rui. A responsabilidade civil. O novo Código Civil: estudos em homenagem a Miguel Reale. São Paulo: LTr, 2003.

TELLES JR, Goffredo. O direito quântico. 5 ed. São Paulo: Max Limonad, 1980.

VARESANO, Iádia de O. A polêmica recepção dos punitives damages no direito brasileiro. Revista Síntese-Direito empresarial, 30: 9-33

VAZ, Carolina. Funções da responsabilidade civil: da reparação à punição e dissuasão: os punitive damages no direito comparado e brasileiro. Porto Alegre: Livraria do Advogado, 2009.

VIEGAS, Claudia M. de A. R e GUEDES, Nayara E. Aplicação dos punitive damages nas relações consumeristas. Revista Síntese-Direito Civil e Direito Processual Civil, 101: 69-103. ZANELATTO, Marco Antonio. Considerações sobre o conceito jurídico de consumidor, Estratégica. Revista da Faculdade de Administração FAAP e do FAAP-MBA, 2:34-57. ZANNONI. El daño em la responsabilidad civil. Buenos Aires: Astrea, 1982. 